\title{
Academic conferencing in the age of COVID-19 and climate crisis: The case of the Comparative and International Education Society (CIES)
}

\author{
Janna Goebel, et al. [full author details at the end of the article]
}

Accepted: 5 November 2020 / Published online: 27 November 2020

(c) UNESCO Institute for Lifelong Learning and Springer Nature B.V. 2020

\begin{abstract}
In this article, organisers of the annual conference of the Comparative and International Education Society (CIES), held during March and April 2020, share their story of moving the planned on-site conference to a virtual space, as necessitated by the COVID19 pandemic. Their analysis of the vCIES (the name given to the virtual conference) process not only provides an example of a disruption to the status quo of the institution of conferencing as a result of a global pandemic, but also extends it by addressing the multiplying concerns, urgent considerations and actions needed within academic communities for more equal and accessible conferencing in the unfolding climate catastrophe. The authors begin by discussing the challenge of academic conferencing in the age of COVID-19 and climate crisis. They highlight how their decolonial political stance (which critiques accepting Western knowledge and Western culture as the norm) and their climate-conscious approach informed their preparation of a virtual conference pilot already intended as an experimental extension to this year's on-site event. They suggest the development of this pilot provided the necessary platform for transforming the vCIES into an effective and engaging virtual experience for participants. The vCIES process, including considerations concerning its structure and format and the necessary technology, is detailed in the subsequent sections. In the final part of their article, the authors briefly identify and discuss some of the opportunities, challenges and implications emerging from their vCIES experiences. Ultimately, they suggest that in a time of instability, insecurity and uncertainty, there need to be alternatives to large on-site conferences which require excessive and extensive academic mobility. The vCIES was a step in that direction as an accessible, environmentally responsive, more equal, and intergenerational and multispecies event that welcomed families, children and pets, while opening the space for new interdisciplinary encounters.
\end{abstract}

Keywords academic conferences $\cdot$ virtual events $\cdot$ decoloniality or decolonial project $\cdot$ equity $\cdot$ COVID-19 pandemic $\cdot$ climate crisis

Co-author names are presented alphabetically to reflect the equal contributions of each individual in the production of this article. 


\section{Résumé}

Les congrès scientifiques à l'ère de la COVID-19 et de la crise climatique : le cas de la Comparative and International Education Society (Société d'éducation comparée et internationale/CIES) - Dans cet article, les organisatrices de la conférence annuelle de la CIES, qui s'est tenue en mars-avril 2020, nous racontent comment, contraintes par la pandémie de COVID-19, elles ont transplanté une conférence prévue en présentiel dans un espace virtuel. Leur analyse de la vCIES (comme elles ont baptisé la conférence virtuelle) illustre l'effet disruptif de la pandémie mondiale dans le contexte des congrès. Elle aborde toutefois aussi cette question dans l'optique des préoccupations qui se multiplient, des questions pressantes qui se posent et des actions devenues nécessaires au sein des communautés scientifiques pour instaurer davantage d'égalité et d'accessibilité en ce qui concerne les conférences, et ce sur le fond de la catastrophe climatique qui se joue actuellement. Les auteures se penchent d'abord sur le défi posé par les congrès scientifiques à l'ère de la COVID-19 et de la crise climatique. Elles soulignent la mesure dans laquelle leur position politique décoloniale (critiquant le fait que la culture et le savoir occidentaux sont acceptés comme la norme) et leur approche qui intègre les questions climatiques ont étayé la préparation de cette conférence pilote virtuelle initialement prévue pour s'inscrire dans le prolongement de la conférence en présentiel de cette année. Elles indiquent que le développement de cette formule pilote leur a fourni l'espace nécessaire pour que la vCIES offre à ses participants une expérience virtuelle efficace et attrayante. Dans les chapitres suivants, elles présentent en détail le déroulement de la vCIES, en abordant notamment des questions liées à sa structure, à son format et à la technique nécessaire à sa mise en œuvre. Dans la dernière partie de l'article, les auteures identifient et abordent un certain nombre de possibilités, de défis et d'implications découlant de leur expérience de la vCIES. À la fin, elles indiquent que dans une période marquée par l'instabilité, l'insécurité et l'incertitude, il faut proposer des solutions de rechange aux grands congrès en présentiel qui exigent des scientifiques des déplacements massifs. Manifestation accessible, écoresponsable, plus équitable, intergénérationnelle et plurispécifique, puisqu'elle a accueilli des familles, des enfants et des animaux de compagnie, tout en offrant un espace à de nouvelles rencontres interdisciplinaires, la vCIES a fait un pas dans cette direction.

\section{Introduction}

By February 2020, amidst growing concern about the spread and effects of the COVID-19 pandemic, organisers of academic conferences around the world scheduled for the first half of the year were confronted with a stark reality: to help protect public health and safety, on-site conferences would have to be cancelled. The relatively easy part was recognising that it would be short-sighted, irresponsible and unethical to crowd hotels with thousands of international conference-goers simply to continue business as usual. Much more difficult than deciding to cancel on-site conferences were decisions about whether and how to proceed with moving conference activities online. Could virtual spaces offer participants what they needed and wanted in terms of sharing their work and learning from others? Could virtual 
spaces effectively facilitate knowledge production and mobilisation ${ }^{1}$ as one of the purposes of scholarly societies? What sorts of knowledge and skills and, more generally, what human and technical resources would be necessary to create a meaningful academic exchange (conference) premised on virtual presence?

The Comparative and International Education Society (CIES) ${ }^{2}$ is an example of a professional association whose on-site conference, scheduled for March 2020 in Miami, Florida, had to be cancelled due to COVID-19 concerns. In this article, as members of the conference organising team, we describe and analyse the process involved in shifting a 3,000+ person on-site conference to a virtual one in a matter of weeks. Accomplishing this task was fraught with uncertainty and challenges abounded, yet with creativity, experimentation and community efforts, the vCIES ${ }^{3}$ (the name given to the virtual conference) became a reality. Online sessions took place during March and April 2020, and the recordings of these sessions have been available since then on the conference website for review and engagement. This achievement is particularly significant considering that despite some initial communications about moving their (northern hemisphere) spring 2020 conferences online, other groups - such as the American Educational Research Association (AERA) and the Comparative and International Education Society of Canada (CIESC) - ultimately decided not to proceed in this direction.

As CIES conference organisers, we were able to rapidly transition to a fully online event in large part because we had already started to explore academic conferences as sites for knowledge production and its related geopolitics (politics influenced by geographical factors). As a result, we had developed a virtual conference pilot programme to extend the annual on-site event and included it in the originally scheduled programme. Our decolonial ${ }^{4}$ political stance and climate-conscious approach, as well as the existing virtual conference extension, provided the necessary foundation and structure to build upon, which enabled us to move forward with the larger transition of on-site conference activities into the virtual space. Learning from the experience of other nearly carbon-neutral conferences, ${ }^{5}$ we created innovative platforms and engagement opportunities, which could then be expanded and further experimented with during the transition to the fully virtual event.

Our story of the vCIES process starts from early discussions in relation to the virtual pilot - advocating for more equal (i.e. in terms of members' geopolitical location, gender, socio-economic status and/or their status as students, practitioners and

\footnotetext{
${ }^{1}$ Knowledge mobilisation refers to connecting research with end users and policymakers, for example.

${ }^{2}$ CIES was established as an academic association in 1956. Its mission is to foster cross-cultural understanding and scholarship. For more information, visit https://www.cies.us/page/About.

${ }^{3}$ Visit the conference website at https://cies2020.org/.

${ }^{4}$ Decoloniality refers to a critique of Eurocentric frames of knowledge production. Nelson MaldonadoTorres suggests that "The decolonial turn does not refer to a single theoretical school, but rather points to a family of diverse positions that share a view of coloniality as a fundamental problem in the modern (as well as postmodern and information) age, and of decolonization or decoloniality as a necessary task that remains unfinished" (Maldonado-Torres 2011, p. 11).

${ }^{5}$ Nearly carbon-neutral conferences create alternative platforms to reduce the need for travel and energy consumption and in this way achieve a zero-carbon footprint, or at least a nearly-neutral one (Hiltner 2020).
} 
researchers not determining who can participate) and nearly carbon-neutral conferencing - and ends following the formal conclusion of live online events (including a film festivalette, artist-in-residence and other experimental fora), with some reflections on challenges and opportunities, as well as their significance and implications for professional associations more broadly. We emphasise the urgent need and possibilities for new academic practices and professional exchanges, instead of conceptualising an activity solely in terms of the function it replaces (in this case, converting on-site to online conferencing). We also argue that it is necessary to apply technology in ways that optimise the unique strengths and attributes of academic conferences in fostering intellectual exchange and networking. We highlight not only the challenges we faced and manged to overcome, but also the valuable opportunities we had, as organisers, to think critically and creatively, to consider a diverse range of participant needs (including those of students, academics and practitioners from low-, middle- and high-income countries) and to learn about, select and use appropriate technologies - as well as to communicate all of this in the most accessible and transparent way possible. Ultimately, in this article we share the promise of what we created together: an alternative to in-person conferences with a view that scientific knowledge production has been intimately bound up with extensive academic mobility (Livingstone 2003, cited in Jöns 2008), which is becoming untenable in the context of climate catastrophe.

\section{Facing the challenge: academic conferencing in the age of COVID-19 and climate crisis}

The CIES response to COVID-19 was determined and framed by several broader considerations relating to political, ethical, economic and environmental concerns that the Society and its members have grappled with over the years.

\section{Political concerns: the 2017 travel ban and the boycotting of US venues}

First, the travel ban instituted by the Trump administration in early $2017,{ }^{6}$ forbidding people from some Muslim countries to enter the United States (US), triggered a stream of international boycotts of academic conferences organised within the US. Given that approximately half of CIES membership is not from the US, the travel ban affected conference participation in at least two ways. While some members were banned from entering the US, others actively chose not to attend conferences held in the US as a form of protest. Conferences are viable venues to illustrate

\footnotetext{
${ }^{6}$ Executive Order 13769 "Protecting the Nation from Foreign Terrorist Entry into the United States" (US President 2017a), which was politically labelled as a Muslim travel ban, was issued by President Trump on 27 January 2017 and was in effect until 6 March 2017, when it was superseded by Executive Order 13780 "Protecting the Nation from Foreign Terrorist Entry into the United States" (US President $2017 \mathrm{~b}$ ), which places limits on travel to the US by nationals of several countries.
} 
through collective absences the grave harms caused by far right ${ }^{7}$ and populist shifts in current politics in many parts of the world. Boycotts and other forms of political activism help generate the political will and memory needed for continued collective action. Initially, a handful of members contacted the CIES Board of Directors to not merely respond with opposition to the executive orders, but to take an active stand and develop diverse modes of dissent and longer-term strategies. They also invited other members to participate in debate during the conference, and to decide on actions and bring them to fruition. The travel ban highlighted the existing challenges of lengthy visa applications, unaffordable visa fees and travel to the US, and the continued political positioning of the US as an Empire.

\section{Decolonial approach: aiming to flatten academic hierarchies}

Second, at approximately the same time, there were strengthening efforts among CIES members to critique and confront the Western dominance of the field of education. These efforts were energised by the critiques of academic knowledge production linked to capitalist globalisation and the different stages of colonisation and neo-colonisation ${ }^{8}$ (Maldonado-Torres 2007). These critiques originated in the struggles of the Global South against colonial rules (Altbach and Kelly 1978), as well as in response to the persisting colonial legacies in education and subsequent international development assistance grounded in Western perspectives (Cowen 2006; Hickling-Hudson 1989, 2007; Samoff 1999; Tikly 2004; Tikly and Bond 2013). Although colonial rule has ended in most places around the world, its legacies remain. As Walter Mignolo (2011) explains, decolonisation has to be addressed not only as a geographical issue aimed at expelling the coloniser from colonised territories, but also as an epistemic ${ }^{9}$ one aimed at the decolonisation of knowledge (see also Takayama et al. 2017; Silova et al. 2017; Manion et al. 2020).

Reproducing the hierarchies of knowledge production in comparative education, ${ }^{10}$ the continuity of coloniality along racialised/cultural lines needs to be

\footnotetext{
7 Far right politics refers to the perspectives of political parties or groups that tend to be "anti-system" and "hostile to liberal democracy" as defined by Cas Mudde (2019, p. 15). Mudde further suggests that the far right is comprised of two sub-groups. First is the extreme right, which "rejects the essence of democracy, that is popular sovereignty and majority rule [e.g., fascism]". Second is the radical right, which "accepts the essence of democracy, but opposes elements of liberal democracy, most notably minority rights, rule of law, and separation of powers" (ibid., pp. 15-16). Populism is defined "as a (thin) ideology that considers society to be ultimately separated into two homogenous and antagonistic groups, the pure people and the corrupt elite, and which argues that politics should be an expression of the volonté générale (general will) of the people" (ibid., p. 16).

${ }^{8}$ Neo-colonialism refers to the political and other (often economic) control exerted by a more powerful nation over a smaller and usually independent nation. According to Philip Altbach (1982), the term "neocolonialism" refers not only to the continuation of past colonial practices but also to explicit attempts by the colonising nations to maintain their influence in their former territories (cited in Nguyen et al. 2009, p. 110).

9 Epistemology refers to the nature of knowledge.

10 Comparative education is a social science discipline which compares educational systems of different countries or regions.
} 
further questioned, especially because it unproblematically attaches itself to scientific authority. "Othering"11 contributes to devaluing alternative worldviews and scholarly work and participation emerging from non-Western spaces and scholars. Types of othering are expressed in academic practices that often exclude non-white, non-Western (female) academics from societies and editorial boards of field-specific journals (Hickling-Hudson 2007). They also disregard alternative knowledge systems, while distinctively applying theoretical traditions and categories that originate in the West as interpretative frames for empirical ${ }^{12}$ cases far removed from the locations where these viewpoints were first developed (Takayama 2016; Silova et al. 2017).

Physical movement of academics, including the attendance of conferences, initiates a circular process of going away, meeting other people and returning, which contributes to knowledge production (Jöns 2008). In his book Science in Action, Bruno Latour (1987) describes three ways in which the movement of academics is related to knowledge production. First, movement mobilises new and often unexpected resources for knowledge production; second, academics can test the value of their newly constructed truth claims; and third, they can also spread arguments and facts in time and space. Thus we ask: how can exchanging physical movement with virtual spaces bring about these benefits of movement and at the same time flatten academic hierarchies - both along colonial and other lines, such as gender and generational politics of academic societies - and thus also diversify ways of thinking and knowing?

\section{Economic considerations: choosing the venue}

Third, these critiques have merged with other dissenting voices that sought to move conferences out of expensive corporate hotels. Besides economic considerations, this push-back against contracts with large hotel chains reflects various ethical considerations as well. Corporate chain hotels in the US are not created to benefit hotel workers; they often deny employees fair wages and benefits, and these hotels are unaffordable for many adjuncts, ${ }^{13}$ graduate students, untenured (non-permanent) academics or those who are coming from less prosperous regions. These are spaces

\footnotetext{
11 Othering refers to excluding and marginalising members of other groups from one's own group. Kevin Kumashiro defines 'the concept of 'other' (the noun) with reference to groups 'that have been traditionally marginalized in society, i.e., that are other than the norm"' (Kumashiro 2000, p. 26, cited in Borrero et al. 2012, p. 3, italics included in citation). Noah Borrero et al. further explain that "the concept of the 'other' has also been used to distinguish children and students who are not part of the norm and who do not belong to dominant cultural or national identity groups" (Borrero et al. 2012, p. 3, citing Devine et al. 2008). As a verb, othering can be defined as "a personal, social, cultural, and historical experience involving (a) cultural and racial ambiguity, (b) categorization and labeling, (c) hierarchical power dynamics, and (d) limited access to resources" (Borrero et al. 2012, p. 3).

12 Empirical cases are evidenced by observation/experience rather than theory alone.

13 Adjunct academics are on limited-term contracts and are not full members of an institution. In some parts of Europe they are not paid, only associated with an institution.
} 
of uneven capital ${ }^{14}$ accumulation. The current US president himself is a hotel magnate, a key detail that too often gets left out when discussing the business alliances of corporate hotels that host large conferences held by organisations like CIES.

\section{Environmental impacts: academic mobility and carbon footprints}

Fourth, while the possibility of a virtual conference to partially address these critiques and concerns first arose in 2017, the urgent need to act on the imminent climate crisis further fortified the vCIES efforts. There was a growing consensus among many academic societies that our business-as-usual practices had to be radically rethought to take into consideration environmental concerns. By 2019, traditional conferencing formats with jet-flying academics became the epicentre of debates demanding that academic (infra)structures, knowledge systems, valuation systems and communications patterns must immediately change (Fresh Ed 2019; Levine et al. 2019; Kier-Byfield 2019). Many scientists and academics across the world pledged to fly less or not at all in order to raise public awareness of the climate impact of frequent flying and enable large-scale change. ${ }^{15}$ While the no-fly campaign has affected CIES conferences only marginally until now, it has definitely added to the growing awareness of and concerns about the Society's environmental footprint among many of its members.

\section{Culmination: vCIES 2020 “Education Beyond the Human”}

Combined, these growing political, ethical, economic and environmental concerns have culminated in an official response, which was manifested in the CIES 2020 conference theme and its operationalisation both at the conceptual, as well as structural and organisational levels. Dedicated to the theme "Education Beyond the Human", ${ }^{16}$ the CIES 2020 annual conference aimed to interrogate the concepts of human exceptionalism and (neo)liberal individualism as the dominant forces behind irreversible ecological catastrophe and the persisting geopolitical hierarchies of Global North/South and East/West academic centres and peripheries. At the same time, the conference planning committee made a commitment not only to discuss these ideas theoretically, but also to explore concrete ways of redrawing the existing academic lines and professional practices by piloting a small virtual extension of the on-site conference. In addition to hybrid (both on-site and online) sessions and online sessions and posters, ${ }^{17}$ which would run in parallel to the on-site conference

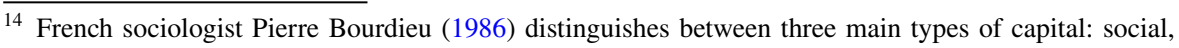
economic and cultural.

${ }^{15}$ See, for example, https://noflyclimatesci.org and https://academicflyingblog.wordpress.com, among other efforts [both accessed 21 October 2020].

${ }^{16}$ A video recording of CIES President Iveta Silova's Welcome to CIES 2020 is available at https:// vimeo.com/399713670.

${ }^{17}$ Academic posters are displayed at conferences to visually present research; poster presenters also engage in discussion with their audience.
} 
programme, we brought together the CIES community in an agora (central meeting place $)^{18}$ to re-examine how we conceive and value academic conferences, and to rethink - and recreate - academic engagements as a way of "speaking back" to the wider structures of power, political economy and privilege that structure knowledge production in general and academic conferences in particular.

Our pilot virtual extension of CIES 2020 Miami was ready to be launched when the COVID-19 global health pandemic broke out, resulting in mass cancellations of academic events across the world. For us, this situation presented an unexpected opportunity to scale up the virtual conference pilot and demonstrate the possibilities it held for addressing the myriad political, ethical, economic and environmental challenges, as well as the most recently added public health concerns. More importantly, the urgency of the COVID-19 response triggered an alarming realisation that the future was already here. There was no longer time to take small, incremental steps. We had to transform our academic practices, movements and ways of being - now.

\section{Engaging with the challenge: expanding the virtual CIES}

When COVID-19 infections first broke out in China in December 2019 and then rapidly spread to other countries in Asia, it felt serious but also distant to many North American academic societies, including CIES. Concerned that our Chinese (and soon after our South Korean and Japanese) colleagues would not be able to attend the conference, the CIES 2020 planning committee made their first effort to expand virtual participation for those members who were immediately affected by COVID19 due to travel restrictions or health issues. This initial expansion included opportunities for CIES members directly affected by COVID-19 (approximately 200 people) to pre-record their individual presentations (e.g. papers or posters) which would be publicly shared on the conference website, or to present in virtual panel sessions or hybrid on-site/online panels. However, as the number of countries with confirmed cases continued to rapidly increase through February and March, it became clear that the spread of COVID-19 would affect everyone's participation.

Making the decision to cancel the on-site event and move into the virtual space was not straightforward. It entailed figuring out not only the technical and technological issues, but also addressing economic and ethical ones. In particular, contracts with corporate hotels meant punitive cancellation fees, which some hotels were reluctant to negotiate even when the governor of Florida had officially announced a state of emergency. Furthermore, a possibility of refunding all registered participants would mean immediately bankrupting the Society, which has historically operated on a fairly modest annual budget. Moreover, even in the context of a global health pandemic, a transition to a fully virtual event was difficult for some CIES Board members and the broader constituency to accept. Despite these concerns, after consultations with the conference planning committee and careful

18 Visit the Agora on Carbon Free and More Equal Conferencing at https://cies2020.org/agora/. 
consideration of different financial scenarios, the CIES Board unanimously voted on 5 March 2020 to cancel the on-site conference and move as much of the conference programming as possible into the virtual space, offering registration refunds only to graduate students and members from low-income countries.

The cancellation of the on-site conference and subsequent expansion of the virtual conference pilot required us, as the programme team, to consider myriad participation options that would maximise the reach of the programme and accommodate participants' needs, while minimising growth beyond our capacity and the possible decline in programme quality which would result. As a small team of five women, with a quick transition window of three weeks to convert the conference to an online event and considering the conference magnitude of approximately 3,000 originally planned on-site participants, we opted to rely on a decentralised, self-organising approach. As a result, the success of the vCIES depended on conference participants' willingness and ability to work together to (re)create a common space and purpose to construct a dynamic, interactive and inclusive virtual conference.

\section{Developing a concept note}

Building upon the structure of the virtual conference pilot, we developed and shared a concept note ${ }^{19}$ to guide participants in moving from CIES 2020 to the vCIES, and the subsequent conversion of their work to synchronous (real-time) and asynchronous (not occurring in real-time; accessed as needed) vCIES presentations. This framing concept note explained our goal to keep space open for decentralised and organic (naturally evolving) experimentation that would be facilitated by the programme planning committee, Standing Committees and Special Interest Groups (SIGs), and would rely heavily on the direct involvement of participants themselves in (re)scheduling their work in the virtual space. The revised call for virtual participation invited authors to fill out an online form linked to a database to let the programme team know if they were able to keep their original time slot and presentation type or if they wished to convert their work to a different presentation format, such as an asynchronous poster or recorded video presentation. The programme team managed the communications with the general participants, and the SIG and Standing Committee programme chairs (organisers) were instrumental in the communication of this plan to their members, which helped to expand the depth and breadth of the programme.

\section{Selecting suitable software}

While there is a range of software available to assist with conference planning, the system traditionally used to coordinate the CIES conference was developed for onsite events, and it lacked the flexibility needed to quickly reschedule the entire programme and move to a virtual conference. Therefore, following our adaptive and

19 The concept note is available at https://cies2020.org/virtual/. 
flexible approach to the vCIES, the conference team opted to utilise a cloud-based software called Airtable, ${ }^{20}$ which allowed us to fairly easily translate online scheduling submission forms into a "living" calendar housed on our conference website. As an open-access public forum, the conference website served as a centralised information hub and content repository for the vCIES. Additionally, to support those who might be uncomfortable navigating new technology or an unfamiliar programme format, we also created weekly programme overviews in PDF format. We shared these weekly programme overviews on the conference website, in weekly conference newsletters to the CIES membership mailing list and via social media throughout the duration of the conference, expanding vCIES access to those who may not have been able or may not even have planned to travel to Miami for the on-site event.

\section{Launching and running the conference}

The vCIES conference began on 15 March 2020 as originally planned in the pilot extension. It continued until the end of April 2020, to allow sufficient time and flexibility for participants to reschedule their conference presentations based on their own schedules and commitments. Officially, we refer to the vCIES timeline as "15 March-30 April, and beyond", as content that we uploaded to the website repository will remain there permanently for historical records. This approach allowed participants to unfold as much of the conference programme as possible into the virtual space, while being mindful of different time zones and preparations necessary for online participation. It also offered different platforms across which to connect, created a rhythm and a space for continued scholarly exchange after the official conference dates, and encouraged "slow" research (see Stengers 2018; Hackett and Somerville 2017; Millei and Rautio 2017) ${ }^{21}$ and an ongoing exchange of ideas.

The vCIES "Education Beyond the Human" conference was conceptualised and advertised as an intergenerational and multispecies event that welcomed families, children and pets, offering flexibility for participants to engage and schedule their conference participation amidst other crises (including loss of childcare, loss of income, having to care for a family member who became sick or becoming sick themselves due to COVID-19) and without fear of scrutiny for any interruptions (including by pets, partners, parents and/or kids). The strategic use of social media (e.g. Twitter) around the hashtag \#vCIES also stimulated scholarly exchange outside the confines of the conference schedule. One outcome of the collaborative nature of the virtual conference transition was a rich and varied virtual conference programme that was widely accessible. Table 1 presents an overview of the programme.

The vCIES conference began during an ongoing period of stress and trauma around the globe where the top priority was and remains caring for each other - our families, friends, colleagues, ourselves and our planet. For this reason, the primary goal of the vCIES was to keep the space open for everyone who found it important,

\footnotetext{
${ }^{20}$ For more information about Airtable, visit https://airtable.com/.

21 Slow research is a complex philosophy, but in a nutshell, it refers to a preference for curiosity-driven scientific research over performance-driven academic research output.
} 
necessary or comforting to engage with each other and the conference theme, "Education Beyond the Human", in challenging times. Connecting with our scholarly community - along with our pets, kids, partners and significant others - even when we were unable to connect physically and network in person, provided solace and solidarity when many of us needed it most. At the same time, the self-organising nature of the conference took the pressure off those members who needed to pause and step away from academic conferencing.

\section{Challenges, opportunities and implications for post-COVID academic conferencing}

At the outset of this discussion concerning the significance and implications of the vCIES experience in the context of post-COVID-19 academic conferencing, it is important to recognise that the crisis has not so much started conversations about virtual conferences as accelerated them. While the online space/format poses numerous technical and organisational challenges, as we discuss below, and forces us to think about the role of mobility in knowledge production, it also offers opportunities for reaching and engaging wider audiences, reducing the carbon footprint of conferences, and addressing equity and inclusivity concerns. The vCIES required participants to try alternative ways of sharing their work and interacting with collaborators, with some of these discussions even pushing researchers, practitioners and policymakers to rethink the concept and benefits of meetings entirely.

\section{Challenges}

\section{Virtual vs. in-person networking and mentoring}

In terms of challenges, beyond the need for extensive physical movement associated with knowledge production as argued by Bruno Latour (1987) and Heike Jöns (2008), and the question about how to recreate the benefits of face-to-face events in a virtual space, we recognise the need to consider people's motivations for spending often considerable amounts of time, energy and money on participating in academic conferences. One of the main reasons people choose to attend these events is to create and maintain networks; however, it is difficult to recreate such opportunities in online spaces. The vCIES included a few means through which to network and mentor early career scholars. For example, the New Scholars Committee's Virtual Speed Mentoring in CIE event, which was held via Zoom, Slack and social media, offered a space for focused mentoring. Additionally, the virtual coffee breaks were low-stakes conversation spaces akin to grabbing a coffee in person. Social media and a collective effort to use the hashtag \#vCIES also helped conference participants to find one another and connect. However, even with these types of efforts, there is considerable room for growth in terms of virtual networking. While networking is a key challenge to address in any online meeting, it is not insurmountable. Therefore, it is important to think carefully and creatively about how to leverage the tools and 
Table 1 vCIES conference programme overview

\begin{tabular}{ll}
\hline Session type & Description \\
\hline Agora & The vCIES conference was launched with the featured "town hall" event* \\
& Academic Conferences During Climate Crisis: Agora on Carbon Free \\
& and More Equal Conferencing. \\
weblink: https://cies2020.org/agora/ & In total, 6 of the 10 originally planned keynote sessions were transi- \\
tioned to the virtual conference programme. All keynote sessions were \\
recorded and made available online for interested conference partici- \\
pants and the broader public to be able to engage with the presentations \\
both during and after the conference. \\
weblink: https://cies2020.org/keynotes/
\end{tabular}

Film festivalette

The Spaces of Education in Film Festivalette was held fully online and organised by the Open Society Foundations**. The films were made available through a password-protected page on the conference website and hosted on Vimeo Showcase. The curators, Adriana Cepeda and Jorge Baxter, hosted live question-and-answer sessions and discussions with the films' directors. These discussions were also recorded and posted on the conference website.

weblink: https://cies2020.org/cies-2020-education-film-festivalette/

Art programme

Virtual workshops

Book launches

Online paper sessions
The vCIES art programme included virtual engagement with the virtual artist-in-residence, Xavier Cortada, who led an interactive Letters to the Future activity to create a participatory conference mural, highlighting intellectual exchange around the conference theme, "Education Beyond the Human". Additionally, art curator Maria Apostolidis transformed CIES participants' visual and performance art sessions into a threedimensional digital art gallery that is hosted on the conference website. weblink: https://cies2020.org/welcome-to-cies-art/

The majority of originally scheduled pre-conference workshops were cancelled due to technical issues or the pedagogical limitations of online space, with 9 out of 31 workshops making the transition to the virtual space.

weblink: https://cies2020.org/pre-conference-workshops

In total, 31 of the 45 originally scheduled book launches were transitioned to the virtual space and are now housed on the conference website.

weblink: https://cies2020.org/virtual/book-launches/

The original virtual conference pilot included 6 online paper sessions, which became part of the expanded virtual conference. Participants pre-recorded their presentations which were made available to audience members to view on their own in advance of the session. During the session itself, participants gave a very brief "elevator pitch" of their papers, *** followed by a thoughtful presentation from a discussant who then led a live moderated discussion with the authors and audience of conference attendees. This format provides more time for discussion, rather than taking most of the session time for presentations. Some of these discussions were recorded and added to the conference website. weblink: https://cies2020.org/virtual-conference/online-paper-sessions/ 
Table 1 (continued)

\begin{tabular}{ll}
\hline Session type & Description \\
\hline Hybrid sessions & The original virtual conference included hybrid sessions where some \\
participants had intended to present remotely. To help avoid technical \\
difficulties during the session, most remote participants pre-recorded \\
their presentations which were to be played during the session, and then \\
the presenters would join for the live discussion. 19 out of 42 hybrid \\
sessions were able to transition to the fully virtual conference, with \\
some presenters using their pre-recorded presentation as opposed to \\
presenting live during the session. \\
Conference organisers provided the opportunity for any panel session \\
group submission to reschedule at any point during the conference. The \\
original conference programme included 391 group panel sessions, \\
including 51 highlighted panels. In total, 132 group panels (including \\
Panel sessions & 12 highlighted sessions) were able to move to the virtual conference.
\end{tabular}

Recorded paper presentations Individuals submitted their recorded paper presentations on a variety of themes, including (1) Education for Sustainable Development, Global Citizenship, and Inclusion; (2) Globalization and Internationalization in Higher Education; (3) Equity and Diversity in Higher Education; (4) Innovations in Youth Workforce Development and Education; (5) Multicultural Perspectives on Education in Global Contexts; (6) Comparative Perspectives on Gender and Sexuality in Education; (7) Education Governance, Funding, and Partnerships; and (8) Access and Equity in Education. These presentations, 91 in total, are now housed on the conference website.

Virtual posters weblink: https://cies2020.org/recorded-papers/

The original virtual pilot extension and on-site conference programme included 77 virtual and 132 on-site poster presentations. A total of 103 posters made the transition to the vCIES and are available to view on the conference website. Each page is enabled with a section to share comments and dialogue with the authors. Virtual poster presenters were also given the opportunity to submit a brief audio clip of their research "elevator pitch" to be shared alongside their poster. weblink: https://cies2020.org/virtual/posters/

Virtual coffee breaks Throughout the dates of the vCIES, virtual coffee breaks were held via video chat as a space to bring together scholars from around the world for informal networking.

Speed mentoring

The New Scholars Committee organised a speed mentoring event across platforms including Zoom, Slack (both are web conferencing systems) and social media, pairing new scholars with senior scholars for a day of focused mentoring.

Business meetings

33 Special Interest Group and Standing Committee business meetings were held virtually via various videoconferencing platforms.

Notes: *A town hall event is an informal gathering for sharing information

** Open Society Foundations (OSF) is a large international grant-making network, founded by George Soros in 1993. OSF has been sponsoring and coordinating film festivalettes at CIES conferences for nearly a decade.

*** An elevator pitch is a persuasive promotion which is so brief that you could present all of it to your target audience on an elevator ride before they reach their exit floor. 
platforms that are available to create meaningful opportunities for both formal and informal networking, while mobilising efforts to reimagine networking itself in our current and post-COVID era.

\section{Obtaining funding approval and recognition for online conferencing}

It is also important to recognise that online education conferences are not yet widely considered to be on the same level as on-site conferences, and universities and international agencies are often unwilling to pay for them. Nonetheless, as we have seen in ad hoc conferences responding to COVID-19, there are certain fields, such as science and engineering, where online conferences are accepted as not only legitimate but also the most up-to-the-minute spaces for sharing new knowledge and engaging in intellectual discussions that are responsive to current issues. Thus, a challenge ahead in the field of education relates to reconceptualising the nature and value of online conferences and promoting a cultural shift in attitudes and behaviours to recognise online conferences as "equally", and perhaps differently, beneficial spaces compared to on-site conferences.

\section{Overcoming hierarchical structures}

This change in paradigm requires us to also engage with the "soft politics" 22 of academic societies, in which tightly knit circles act as gatekeepers deciding whose voice is significant or counts in discussions. As the pandemic made visible the important strata of society ("essential workers") and their productive work - those who care for the sick, children and elderly, and produce and supply our basic human necessities when everything else pauses its operation - virtual conferences also exposed the value-based, political and economic enterprise of academic knowledge production. In our contemporary knowledge organisations (such as universities, disciplinary/ academic societies and international organisations), the value of particular knowledge is encoded in the very organisation and hierarchy of institutions (e.g. task distribution, finances), and in the production and consumption of knowledge commodities (e.g. software, databases, systems of commodity expertise) (Abbott 2017). Here, we must first ask how virtual meetings can create spaces for more horizontal, equal and collaborative "social knowers"23 (ibid.).

\section{Including genuine participants while excluding hostile troublemakers}

Another considerable challenge is the inherent tension between using virtual conferencing to open up access to those who would normally be excluded from onsite conferences and the need to maintain a safe online environment to facilitate

\footnotetext{
${ }^{22}$ In this context, the term soft politics refers to subtle control and influence being exercised as they see fit by a few "inner circle" society members over many others.

23 Social knowers are co-operative knowledge negotiators. "Social knowing changes who does the knowing and how, more than it changes the what of knowledge" (Weinberger 2007, p. 144, italics in original).
} 
meaningful exchanges between participants. Online spaces and platforms can pose serious safety and privacy risks (FBI 2020; St. John 2020). For example, in the early days of the vCIES, a number of sessions were "Zoom bombed" and effectively taken over by abusive harassers intent on derailing events with loud, violent, racist and otherwise disturbing imagery and damaging words. To help protect vCIES participants, we developed and shared technical guidance on how to adjust Zoom settings to guard against the risk of disruption by outsiders. A drawback of the decentralised approach to the vCIES was that, due to the size of the programme committee ( 5 women), and the number of sessions (235) in the conference programme, we were unable to ensure that each individual meeting link had been properly secured. Additionally, some of the protections in place that were meant to slow down nefarious (harmful) interruptions also limited some of the functionalities of the Zoom platform and inadvertently made it more difficult for some vCIES participants to connect. In April 2020, Zoom made changes to their default settings to address the widespread safety and security concerns. Nevertheless, a key challenge with openaccess virtual conferencing remains advertising the schedule widely while ensuring the security of sessions.

\section{Opportunities}

\section{Maintaining (or even increasing) visibility}

A salient takeaway from this impromptu virtual conference experiment was that when pressed to do so, we, as a Society, were able to find a viable alternative to our annual in-person conference. The virtual conference extension allowed for an international gathering that was less costly to the participants and to the environment than a traditional on-site format. In total, the vCIES included 202 parallel sessions ranging in size from small, intimate sessions attended by just a few participants, to our largest keynote session attended by over 300 people with more than 1,000 views on YouTube by June 2020. In addition, the conference website now houses 103 virtual poster presentations along with 91 recorded papers. Over the course of the conference, the CIES Twitter account gained 489 new followers (in contrast to an average of 73 new followers in the three months leading up to the conference) and had 8,295 profile visits (with an average of 652 profile visits a month in the three months prior).

\section{Reducing our carbon footprint}

By transitioning to the virtual conference space, CIES made the first stride towards a more equal and lower-carbon conference in 2020 compared to prior events, saving approximately $4,000 \mathrm{mT} \mathrm{CO} 2 \mathrm{e},{ }^{24}$ which is equivalent to approximately 100,000 trees logged, or approximately 450,000 US gallons (1,703,435 litres) of petrol used,

\footnotetext{
24 These calculations are based on the TerraPass formula for calculating the carbon footprint of events, taking into consideration the venue, travel to/from the airport and domestic/international travel (for more, please see www.terrapass.com). For CIES calculations, we accounted for 50\% international travel.
} 
or approximately 4,407,451 pounds (1,999 metric tons) of coal burned. The diverse participation options, including synchronous and asynchronous presentations, and the decentralised approach which allowed participants to choose the date and time of their presentations, simultaneously flattened some of the hierarchies that are inherent in an in-person, centrally organised conference, while also allowing accessibility for those who have limited internet bandwidth or finances. The "slow" and enduring presence of the vCIES conference experiment also provided an opportunity for more extensive and in-depth feedback on the work presented.

\section{Optimising participants' time management}

In terms of opportunities, we suggest that asynchronous formats are useful tools to help overcome the challenges of time zones and connectivity, as many people cannot effectively participate in a live-streamed session but are able to access online content that requires less bandwidth. The online format can also potentially shift the value and hierarchy of certain forms of presentations and increase the exposure of the person presenting. For example, a keynote presentation might get minimally more or equal exposure in promotion to a paper session, especially if participants promote their own presentations on social media platforms. Besides retaining their presence on the internet, online poster presentations might get more extended discussion (in terms of time and breadth) than an on-site paper session would ever get due to limitations of time and space. In the context of the vCIES, participant survey data (collected after the conclusion of the vCIES) indicated that asynchronous poster presenters, for example, found that these formats allowed them to share their work on a variety of platforms (including the conference website and through social media channels), which significantly furthered the reach of this work overall - both in terms of numbers of people and different disciplinary areas.

\section{Implications: effectiveness}

We would also like to highlight here that for the purpose of a panel session, the vCIES experience suggests that virtual formats can be just as effective as in-person formats. In particular, in vCIES paper sessions, the presentations were pre-recorded and available for viewing prior to the synchronous sessions. This allowed time for discussion and meaningful engagement with the work, which can be an afterthought or rushed encounter in an on-site session when presentations run longer than planned. We also know from our survey that vCIES content resources, including virtual posters and recorded presentations, have already been used for teaching purposes. Courses related to the science and practice of research, as well as those related to the conference theme, "Education Beyond the Human", have already drawn on the conference and its archive. The vCIES experience suggests that it worth reconsidering the many ways in which virtual engagement can supplement inperson conferences so that participation is expanded and people may better engage with each other. 


\section{Conclusion}

We have written this article because we believe there is value in highlighting and sharing the possibilities revealed through the exercise of moving a large international conference into a virtual space. Our descriptive analysis of the vCIES is one example of a disruption to the status quo of the conferencing genre as a result of a global pandemic, but also extends it by addressing the multiplying concerns, urgent considerations and actions needed. While we only had limited space in this article to think further, we have raised important questions about the uneven and unsustainable practices involved in academic work and knowledge production. We believe that the framework we have outlined here provides a starting point to think about conferencing as a part of academic work in new and different ways, especially when focusing on movement in the production, circulation and mobilisation of knowledge. We uphold that the work must start with rethinking the role of large on-site conferences, including their intellectual, social and personal aspects - and their price for our planet. In other words, we are not looking for a substitute but at a new alternative that can address the problems related to geopolitics, continuing colonialism, the soft politics and power hierarchies in academic societies, and the alleged need for extensive and excessive physical mobility.

A more participatory and inclusive way of organising conferences can go a long way in addressing these concerns, while also responding to different considerations of time and space. Creative, intentional and careful use of technology redefines mobility and enables virtual connections in ways that allow us to extend beyond traditional participation and expand the reach of these events.

Looking forward to future conferences, new virtual options should be not only a welcome opportunity, but a necessary change. In a time of instability, insecurity and uncertainty, there need to be viable alternatives to large in-person conferences held in expensive urban centres in large corporate hotel chains. The vCIES was a step in that direction, opening the space for new interdisciplinary encounters as an accessible, environmentally responsive, more equal, and intergenerational and multispecies event that took its theme "Education Beyond the Human" seriously.

\section{References}

Abbott, A. (2017). The future of expert knowledge [video-recorded lecture, 13 December]. Berlin: Wissenschaftszentrum Berlin/Berlin Social Science Center (WZB). Retrieved 23 October 2020 from https://www.youtube.com/watch?v=fSFkljMNegY.

Altbach, P. G. (1982). Servitude of the mind? Education, dependency, and neo-colonialism. In P. G. Altbach, R. F. Arnove, \& G. P. Kelly (Eds.), Comparative education (pp. 469-484). New York: Macmillan.

Altbach, P. G., \& Kelly, G. P. (1978). Education and colonialism. New York, NY: Longman Publishing Group.

Borrero, N. E., Yeh, C. J., Cruz, C. I., \& Suda, J. F. (2012). School as a context for "othering” youth and promoting cultural assets. Teachers College Record, 114(2), 1-37.

Bourdieu, P. (1986). The forms of capital. In J. G. Richardson (Ed.), Handbook of theory and research for the sociology of education (pp. 241-258). New York, NY: Greenwood Press. 
Cowen, R. (2006). Acting comparatively upon the educational world: Puzzles and possibilities. Oxford Review of Education, 32(5), 561-573. https://doi.org/10.1080/03054980600976155.

Devine, D., Kenny, M., \& Macneela, E. (2008). Naming the "other": Children's construction and experience of racisms in Irish primary schools. Race, Ethnicity, and Education, 11(4), 369-385. https://doi.org/10.1080/13613320802478879.

FBI (Federal Bureau of Investigation). (2020). FBI warns of teleconferencing and online classroom hijacking during COVID-19 pandemic [online press release]. Boston: FBI. Retrieved 2 April 2020 from https://www.fbi.gov/contact-us/field-offices/boston/news/press-releases/fbi-warns-ofteleconferencing-and-online-classroom-hijacking-during-covid-19-pandemic.

Fresh Ed. (2019). What is the role of education in times of climate crisis? Fresh Ed, 11 November [audio podcast]. Retrieved 19 October 2020 from https://freshedpodcast.com/climateaction/.

Hackett, A., \& Somerville, M. (2017). Posthuman literacies: Young children moving in time, place and more-than human worlds. Journal of Early Childhood Literacy, 17(3), 374-391. https://doi. org/10.1177/1468798417704031.

Hickling-Hudson, A. (1989). Education in the Grenada Revolution, 1979-1983. Compare, 19(2), 95-114. https://doi.org/10.1080/0305792890190204.

Hickling-Hudson, A. (2007). Cultural complexity, post-colonialism and educational change: Challenges for comparative educators. International Review of Education, 52(1-2), 201-218. https:// doi.org/10.1007/s11159-005-5592-4.

Hiltner, K. (2020). Appendix: Writing a new practice, details, details. In K. Hiltner (Ed.), Writing a new environmental era: Moving forward to nature (pp. 127-151). Routledge environmental humanities series. Abingdon: Routledge.

Jöns, H. (2008). Academic travel from Cambridge University and the formation of centres of knowledge, 1885-1954. Journal of Historical Geography, 34(2), 338-362. https://doi.org/10.1016/j. jhg.2007.11.006.

Kier-Byfield, S. (2019). As an academic, should I worry about my conference carbon footprint? The Guardian, 11 June [online article]. Retrieved 29 October 2020 from https://www.thegu ardian.com/education/2019/jun/11/as-academics-should-we-worry-about-our-conference-carbo n-footprint.

Kumashiro, K. K. (2000). Toward a theory of anti-oppressive education. Review of Educational Research, 70(1), 25-53. https://doi.org/10.3102/00346543070001025.

Latour, B. (1987). Science in action: How to follow scientists and engineers through society. Milton Keynes: Open University Press.

Levine, C., et al. (2019). Reducing the carbon footprint of academic travel. Inside Higher Education, 18 April [online article]. Retrieved 29 October 2020 from https://www.insidehighered.com/ views/2019/04/18/12-scholars-share-ideas-reducing-carbon-emissions-academic-travel-opinion.

Livingstone, D. N. (2003). Putting science in its place: Geographies of scientific knowledge. Chicago, IL: University of Chicago Press.

Maldonado-Torres, N. (2007). On the coloniality of being: Contributions to the development of a concept. Cultural Studies, 21(2-3), 240-270. https://doi.org/10.1080/09502380601162548.

Maldonado-Torres, N. (2011). Thinking through the decolonial turn: Post-continental interventions in theory, philosophy, and critique-An introduction. Transmodernity: Journal of Peripheral Cultural Production of the Luso-Hispanic World, 1(2), 1-15. https://escholarship.org/uc/item/59w8j $02 \mathrm{x}$.

Manion, C. P., Anderson, E. A., Baily, S., Call-Cummings, M., Iyengar, R., Shah, P., \& Witenstein, M. A. (Eds). (2020). Interrogating and innovating comparative and international education research. New research-New voices series, (Vol. 9). Leiden \& Boston: Brill Sense.

Mignolo, W. D. (2011). The darker side of Western modernity: Global futures, decolonial options. Durham, NC: Duke University Press.

Millei, Z., \& Rautio, P. (2017). "Overspills" of research with children: An argument for slow research. Children's Geographies, 15(4), 466-477. https://doi.org/10.1080/14733285.2016.1277182.

Mudde, C. (2019). The far right today. Cambridge: Polity Press.

Nguyen, P. M., Elliott, J. G., Terlouw, C., \& Pilot, A. (2009). Neocolonialism in education: Cooperative learning in an Asian context. Comparative Education, 45(1), 109-130. https://doi. org/10.1080/03050060802661428.

Samoff, J. (1999). No teacher guide, no textbooks, no chairs. In R. F. Arnove \& C. A. Torres (Eds.), Comparative education: The dialectic of the global and the local (pp. 393-943). Plymouth: Rowman \& Littlefield. 
Silova, I., Millei, Z., \& Piattoeva, N. (2017). Interrupting the coloniality of knowledge production in comparative education: Postsocialist and postcolonial dialogues after the Cold War. Comparative Education Review, 61(S1), S74-S102. https://doi.org/10.1086/690458.

St. John, A. (2020). It's not just Zoom. Google Meet, Microsoft Teams, and Webex have privacy issues too. Consumer Reports, 3 April [online article]. Retrieved 05 May 2020 from https:// www.consumerreports.org/video-conferencing-services/videoconferencing-privacy-issues-googl e-microsoft-webex/.

Stengers, I. (2018). Another science is possible: A manifesto for slow science. Medford, MA: Polity Press.

Takayama, K. (2016). Deploying the post-colonial predicaments of researching on/with "Asia" in education: A standpoint from a rich peripheral country. Discourse: Studies in the Cultural Politics of Education, 37(1), 70-88. https://doi.org/10.1080/01596306.2014.927114.

Takayama, K., Sriprakash, A., \& Connell, R. (2017). Toward a postcolonial comparative and international education. Comparative Education Review, 61(S1), S1-S24. https://doi.org/10.1086/69045 5 .

Tikly, L. (2004). Education and the new imperialism. Comparative Education, 40(2), 173-198. https ://doi.org/10.1080/0305006042000231347.

Tikly, L., \& Bond, T. (2013). Towards a postcolonial research ethics in comparative and international education. Compare: A Journal of Comparative and International Education, 43(4), 422-442. https://doi.org/10.1080/03057925.2013.797721.

US President (President of the United States of America). (2017a). Executive Order No. 13769: Protecting the nation from foreign terrorist entry into the United States. Issued 27 January. Washington, DC: The White House. Retrieved 21 October 2020 from https://www.federalregister.gov/ documents/2017/02/01/2017-02281/protecting-the-nation-from-foreign-terrorist-entry-into-theunited-states.

US President. (2017b). Executive Order No. 13780: Protecting the nation from foreign terrorist entry into the United States. Issued 6 March. Washington, DC: The White House. Retrieved 21 October 2020 from https://www.federalregister.gov/documents/2017/03/09/2017-04837/protecting -the-nation-from-foreign-terrorist-entry-into-the-united-states.

Weinberger, D. (2007). Social knowing. In D. Weinberger (Ed.), Everything is miscellaneous: The power of the new digital disorder (pp. 129-147). New York, NY: Holt.

Publisher's Note Springer Nature remains neutral with regard to jurisdictional claims in published maps and institutional affiliations.

Janna Goebel, $\mathrm{PhD}$, is a recent graduate of the Educational Policy and Evaluation doctoral programme of the Mary Lou Fulton Teachers College at Arizona State University. Janna's research focuses on the ways that education can be conceptualised beyond the human and explores how relationships among humans and the more-than-human world matter in how we approach sustaining life on Earth.

Caroline Manion, $\mathrm{PhD}$, is an Assistant Professor, Teaching Stream, in the Educational Leadership and Policy programme, Department of Leadership, Higher and Adult Education, cross-appointed with the Comparative, International and Development Education Collaborative Specialization, at the Ontario Institute for Studies in Education (OISE), University of Toronto. Her research and teaching practices are grounded in decolonial, international and comparative perspectives, with a focus on equity and social justice issues in education, including with respect to gender, intersectionality, international education governance and policy, education reform, and teachers and teaching.

Zsuzsa Millei, PhD, is a Professor at the Faculty of Education and Culture, Tampere University, Finland. She is interested in the cultural politics of childhood, memory work, nationalism and post-socialist knowledge production. She employs comparisons of different places and times to help highlight how the taken-for-granted ways of Cold War divides, ideologies and everyday nationhood operate.

Robyn Read, $\mathrm{PhD}$, is an independent researcher with a $\mathrm{PhD}$ in Comparative and International Development Policy and Leadership in Education from the University of Toronto. She has served as an instructor 
at the University of Western Ontario, Queen's University, and University of Toronto. Robyn is an active knowledge mobilisation (KMb) professional and has worked with Mastercard Foundation, the Global Partnership for Education, the Comparative and International Education Society, and the Knowledge Network for Applied Education Research. Her research focuses on KMb in education, the global governance of education, and private investment in education.

Iveta Silova, $\mathrm{PhD}$, is professor and director of the Center for Advanced Studies in Global Education at Mary Lou Fulton Teachers College at Arizona State University. She holds a PhD in comparative education and political sociology from Teachers College, Columbia University. Her research focuses on globalisation and postsocialist education transformations, including intersections between post-colonialism and post-socialism after the Cold War. Iveta's most recent research engages with the decoloniality of knowledge production and being, childhood memories, ecofeminism, and environmental sustainability.

\section{Affiliations}

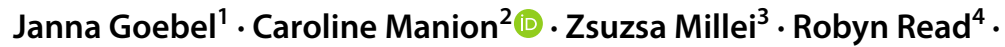 Iveta Silova ${ }^{5}$}

\section{Caroline Manion}

carly.manion@utoronto.ca

Janna Goebel

janna.goebel@gmail.com

Zsuzsa Millei

zsuzsa.millei@tuni.fi

Robyn Read

robyn.b.read@gmail.com

Iveta Silova

Iveta.silova@asu.edu

1 Arizona State University, Tempe, AZ, USA

2 Department of Leadership, Higher and Adult Education, OISE, University of Toronto, Toronto, ON, Canada

3 Faculty of Education and Culture, Tampere University, Tampere, Finland

4 Independent Consultant, Toronto, ON, Canada

5 Mary Lou Fulton Teachers College, Arizona State University, Tempe, AZ, USA 